\title{
Prevalence of Developmental Language Delay among Toddlers Born as Preterm
}

\author{
YoonKyoung Lee ${ }^{\mathrm{a}}$, HyoJoo Lee ${ }^{\mathrm{b}}$ \\ ${ }^{a}$ Division of Speech Pathology and Audiology, Hallym University, Chuncheon, Korea \\ ${ }^{b}$ Department of Speech-Language Pathology and Audiology, Graduate School of Hallym University, Chuncheon, Korea
}

Correspondence: YoonKyoung Lee, $\mathrm{PhD}$ Division of Speech Pathology and Audiology, Hallym University, 1 Hallimdaehak-gil, Chunchon 24252, Korea

Tel: +82-33-248-2219

Fax: +82-33-256-3420

E-mail: ylee@hallym.ac.kr

Received: January 5, 2016

Revised: February 9, 2016

Accepted: February 29, 2016

This work was supported by the National Research Foundation of Korea Grant funded by the Korean government (NRF-2014S1A5A2A01015713) and Hallym University (HRF-201512-008).

\begin{abstract}
Objectives: Being born preterm is one of the factors which affects language development of toddlers. The purpose of this study was to examine language performance and the prevalence of developmental language delay (DLD) among toddlers who were born in preterm condition compared to full-term toddlers. Methods: A total of 165 toddlers, 86 preterm and 79 full-term, participated in this study. The two groups of toddlers were classified into three age groups: 12-18 months, 19-24 months, and 25-30 months. Language abilities were measured using Sequenced Language Scale for Infants (SELSI) and Korean MacArthur-Bates Communication Development Inventory (K M-B CDI). The results of two toddler groups on language tests were analyzed statistically through two independent $t$-test, 2-way ANOVA, and $\chi^{2}$ test. Results: The premature group showed significantly lower receptive language age, expressive language age, and combined language age measured by SELSI and significantly lower frequency of expressive vocabulary measured by K M-B CDI than the chronological age-matched full-term toddler group. The prevalence of DLD and at risk DLD was significantly higher in the preterm than the full-term group. Conclusion: Based on the results of this study we discuss the importance of early language intervention in preterm toddlers for preventing language delay.
\end{abstract}

Keywords: Preterm toddlers, Language development, Prevalence of developmental language delay
최근 들어 신생아학의 급속한 발달과 고령 출산의 증가 등으로 인하여 미숙아 출현율이 증가하고 있다(Phillips, 2006; Schirmer, Portuguez, \& Nunes, 2006). 국내의 경우도 1990년부터 2000년도 까지 약 10 년 동안 조산아 출생빈도가 약 3 배수가 증가되었으며, 2002년에는 4\%였던 미숙아 출생률이 2013년에는 5.5\%로 매해 꾸 준히 증가하고 있다고 보고되었다(Lee, 2014).

미숙아 출생은 아동기, 특히 영유아기 발달지체의 원인 중 하나 이다(Billeaud, 2003; Lee, 2004; Rossetti, 2001). 미숙아로 출생한 영유아의 발달을 추적한 연구들은 미숙아 출생 아동 집단에서 유 의하게 높은 발달장애 출현율을 보고하였다. Roberts 등(2007)은 미숙아로 출생한 영유아 236명을 추적하여 2세 때 발달검사를 실 시하였는데, 그 중 $50.7 \%$ 가 장애를 가진 것으로 나타났다고 보고하 였다. Marlow, Wolke, Bracewell과 Samara (2005)도 재태기간이
25 주 이하인 조산아 241 명을 30 개월과 6세 때 추적 조사하였는데, 6 세 때 $21 \%$ 의 아동이 -2 표준편차 이하에 해당하는 심한 지적장애 를 보였으며, 이중 22\%는 중도(severe), 24\%는 중등도(moderate), $34 \%$ 는 경도(mild)에 해당하였다. 그리고 30 개월에 중등도에서 중 도에 해당하였던 아동의 $86 \%$ 가 6 세 때에도 여전히 지적장애를 보 여 영유아시기의 발달지연이 유아기까지 지속되었음을 보고하였 다. Marlow, Roberts와 Cooke (1993)은 학령기에 접어들어 읽기나 쓰기와 같은 학습 영역에서도 장애를 보이는 경우가 일반아동들은 $11 \%$ 인 반면, 미숙아들은 약 $45 \%$ 에 달했다고 보고하면서 이들의 발 달문제가 학령기의 학습문제에까지도 영향을 미칠 수 있다고 보고 하였다. 1980년대부터 2001년까지 발표된 미숙아들의 인지기능에 대한 논문 15 편에 대해 메타분석 결과를 보고한 Bhutta, Cleves, Casey, Cradock과 Anand (2002)도 미숙아 출생아들의 인지검사 
점수가 만삭아에 비해 낮으며, 이러한 경향은 학령기까지 지속된다 고보고하였다.

미숙아의 발달지체 문제는 언어발달 측면에서도 다수 보고되었 다(Koldewijn et al., 2009; Lee \& Lee, 2014; Stolt et al., 2014; Taylor, Klein, Minich, \& Hack, 2001). Lee와 Lee (2013)는 1990년대 이후 국외에서 발표된 미숙아 출생 아동의 언어 및 의사소통 발달 관련 연구 30 편을 분석하였는데, 이 중 약 $70 \%$ 인 25 편의 연구가 미숙아 들의 언어 및 의사소통 능력이 정상 출생 영유아에 비해 유의하게 낮았다고 보고하였다. Wolke, Samara, Bracewell과 Marlow (2008) 는 미숙아 출생 아동들이 또래들과 언어발달에서 유의한 차이가 있을 뿐 아니라 언어발달장애의 출현율도 높았다고 보고하였다. 이 들은 미숙아로 출생한 6 세 아동 82 명의 언어와 학업성취를 106 명 의 또래와 비교하였는데, 미숙아 출생 아동들이 모든 말-언어 점수 에서 또래와 유의한 차이를 보였을 뿐만 아니라 말-언어점수에서 -2 표준편차 이하에 해당하는 아동이 전체의 $10 \%-20 \%$ 로 말-언어 장애 출현율이 높았다고 보고하였다.

이처럼 미숙아로 출생한 아동들이 갖는 발달적 위험 때문에 서 구 선진국에서는 Infant Health and Development Program과 같은 발달 촉진 프로그램을 통해 미숙아들의 발달을 돕기 위한 노력들 을 시도해 왔다. 미국의 일부 주(state)에서는 미숙아 출산을 장애위 험(at risk)요인으로 파악하고 이 아동들을 유아특수교육 대상자로 지원하기도 한다(Lee, 2004; Rossetti, 2001). 반면, 우리나라의 경우 지방자치단체에 따라차이가 있으나 미숙아에 대한 지원은 월평균 소득이 $130 \%$ 이하이며 다자녀 가족 중 셋째 자녀 이후의 자녀에게 만 지원하는 등(Park, 2010) 그 지원 정도가 미미하다.

앞에서도 강조하였듯이 미숙아 출생은 언어발달을 포함한 전반 적인 발달지체의 위험 요인이다. 따라서 이들의 발달을 돕는 조기 중재가 이루어져야 할 것이다. 조기중재는 미숙아들이 가질 수 있 는 발달 문제를 사전에 예방 또는 최소화할 뿐 아니라 가족들로 하 여금 아동들에 대한 발달 문제를 이해하고 대처하게 함으로써 가 족기능을 강화할 수 있도록 도와준다. 나아가서는 장애 발생이나 장애가 심화되는 것을 미연에 예방함으로써 추후 이들에 대한 사 회 국가적인 책임을 경감시키는 효과를 갖는다(Lee, 2004; Rossetti, 2001). 특히 언어발달은 일상생활에서의 의사소통의 중요성과 더 불어 언어가 인지나 학업은 물론 사회성 발달 등 발달 전반에 영향 을 미치기 때문에 발달을 촉진하기 위한 조기중재가 무엇보다 중요 하다고 할수 있다(Lee, 2011).

미숙아들의 발달을 지원하기 위한 정책 마련이나 프로그램 개발 을 위해서는 이들의 발달에 대한 연구가 선행되어야 할 것이다. 국 내에서도 미숙아 출생률의 증가와 더불어 미숙아 관련 연구들도
상대적으로 증가하였지만 미숙아와 관련한 국내연구는 대부분 신 체·건강이나 또는 영양과 관련된 연구가 대부분이며(Kim, 2005), 발달에 대한 연구(Kang \& Lee, 2007; Oh, Lee, Lee, \& Kim, 2004)는 그 수가 상대적으로 매우 적다. 본 연구는 이러한 배경 하에 미숙아 출생이 영유아의 언어발달에 미치는 영향을 살펴보는 것을 목적으 로 수행하였다. 구체적인 연구문제는 다음과 같다. 첫째, 미숙아 출 생 영유아는 만삭아 집단과 비교하였을 때 표준화 언어검사 수행 에서 차이가 있는가? 둘째, 두 영유아 집단에서의 언어발달지체 출 현율 및 출현빈도에 차이가 있는가?

\section{연구 방법}

\section{연구 대상}

$12-30$ 개월의 미숙아 출생 영유아 86 명과 미숙아 출생 영유아와 생활연령이 일치한 만삭아 79 명, 총 165 명을 대상으로 하였다. 미숙 아 출생 영유아는 출생 시 몸무게가 $2.5 \mathrm{~kg}$ 미만이며 재태기간이 37 주 미만인 영유아였다. 만삭아 출생 영유아는 출생 시 몸무게가 2.5 $\mathrm{kg}$ 이상이며 재태기간이 37주 이상인 영유아들 중 한국판 베일리 영아발달 검사(Korean-Bayley Scale of Infant Development-II, KBSID-II; Cho \& Park, 2006)를 실시하여 전반적 발달이 '정상발달' 범주에 속하는 영유아로 하였다.

두 영유아 집단에 대한 기본정보는 Table 1 과 같다. 미숙아 집단 은 생활월령 평균이 20.99 개월이었으며, 만삭아 집단은 20.81 개월 로 유의한 차이가 없었다. 출생 시 몸무게는 미숙아 집단이 $1.50 \mathrm{~kg}$, 만삭아 집단은 $3.26 \mathrm{~kg}$ 으로 미숙아 집단이 유의하게 적었으며, 재 태기간도 미숙아 집단이 30.45개월, 만삭아 집단은 39.13개월로 미 숙아 집단이 유의하게 짧았다. K-BSID-II 결과는 미숙아 집단이 인 지영역에서 전체의 58 명(67\%)의 영유아가 $25 \%$ ile 이하(10\%ile 미만 과 10\%ile-25\%ile 사이 합산 수치)였으며, 동작성 영역에서도 57명 (67\%)의 영유아가 $25 \%$ ile 이하의 수행을 보여 절반 이하의 영유아 가 지연된 발달 혹은 발달지연위험을 보였다. 반면, 만삭아 집단에서 는 인지영역에서는 2 명(2.5\%), 동작영역에서 1 명(1.2\%)의 영유아가 발달지연위험을 보였으며 다른 모든 영유아는 정상범위의 수행을 보였다.

\section{연구 도구}

영유아들의 언어능력은 국내 영유아들을 대상으로 표준화된 언 어검사인 영유아 언어발달검사(Sequenced Language Scale for Infants, SELSI; Kim, Kim, Yoon, \& Kim, 2003)와 한국판 맥아더-베 이츠 의사소통검사(Korean MacArthur-Bates Communication 
Table 1. Participants' information

\begin{tabular}{|c|c|c|c|c|c|c|c|c|}
\hline & \multicolumn{4}{|c|}{ Preterm toddler } & \multicolumn{4}{|c|}{ Full-term toddler } \\
\hline & $\begin{array}{c}12-18 \mathrm{mo} \\
(\mathrm{N}=37)\end{array}$ & $\begin{array}{c}19-24 \text { mo } \\
(\mathrm{N}=21)\end{array}$ & $\begin{array}{c}25-30 \mathrm{mo} \\
(\mathrm{N}=28)\end{array}$ & $\begin{array}{c}\text { Total } \\
(\mathrm{N}=86)\end{array}$ & $\begin{array}{c}12-18 \mathrm{mo} \\
(\mathrm{N}=32)\end{array}$ & $\begin{array}{c}19-24 \text { mo } \\
(\mathrm{N}=25)\end{array}$ & $\begin{array}{c}25-30 \mathrm{mo} \\
(\mathrm{N}=22)\end{array}$ & $\begin{array}{c}\text { Total } \\
(\mathrm{N}=79)\end{array}$ \\
\hline Chronological age (mo) & $15.84 \pm 1.625$ & $21.67 \pm 2.058$ & $27.29 \pm 1.782$ & $20.99 \pm 5.277$ & $15.63 \pm 1.996$ & $21.48 \pm 1.806$ & $27.59 \pm 1.681$ & $20.81 \pm 5.243$ \\
\hline Gestational age (wk) & $30.57 \pm 3.768$ & $29.43 \pm 3.265$ & $31.07 \pm 3.265$ & $30.45 \pm 3.507$ & $39.28 \pm 1.170$ & $39.20 \pm 1.041$ & $38.82 \pm 1.368$ & $39.13 \pm 1.191$ \\
\hline Birth weight (kg) & $1.55 \pm .715$ & $1.37 \pm .648$ & $1.53 \pm .524$ & $1.50 \pm .639$ & $3.25 \pm .342$ & $3.29 \pm .273$ & $3.23 \pm .427$ & $3.26 \pm .345$ \\
\hline K-BSID-II & & & & & & & & \\
\hline $\begin{array}{l}\text { Mental scale } \\
\leq 10 \% \text { ile } \\
\text { 11\%ile-25\%ile } \\
>25 \% \text { ile }\end{array}$ & $\begin{array}{c}3(8.1) \\
7(18.9) \\
27(73.0)\end{array}$ & $\begin{array}{r}5(23.8) \\
6(28.6) \\
10(47.6)\end{array}$ & $\begin{array}{c}0(0) \\
2(6.3) \\
30(93.8)\end{array}$ & $\begin{array}{l}37(43.0) \\
21(24.4) \\
28(32.6)\end{array}$ & $\begin{array}{c}0(0) \\
2(6.3) \\
30(93.8)\end{array}$ & $\begin{array}{c}0(0) \\
0(0) \\
25(100)\end{array}$ & $\begin{array}{c}0(0) \\
0(0) \\
22(100)\end{array}$ & $\begin{array}{c}0(0) \\
2(2.5) \\
77(97.5)\end{array}$ \\
\hline $\begin{array}{l}\text { Motor scale } \\
\quad \leq 10 \% \text { ile } \\
11 \% \text { ile-25\%ile } \\
>25 \% \text { ile }\end{array}$ & $\begin{array}{r}8(21.6) \\
7(18.9) \\
22(59.5)\end{array}$ & $\begin{array}{c}1(4.8) \\
9(42.9) \\
11(52.4)\end{array}$ & $\begin{array}{r}4(14.3) \\
5(17.9) \\
19(67.9)\end{array}$ & $\begin{array}{l}37(43.0) \\
21(24.4) \\
28(32.6)\end{array}$ & $\begin{array}{c}0(0) \\
1(3.1) \\
31(96.9)\end{array}$ & $\begin{array}{c}0(0) \\
0(0) \\
25(100)\end{array}$ & $\begin{array}{c}0(0) \\
0(0) \\
22(100)\end{array}$ & $\begin{array}{c}0(0) \\
1(1.2) \\
78(98.8)\end{array}$ \\
\hline
\end{tabular}

Values are presented as mean \pm SD or number (\%).

K-BSID-II=Korean-Bayley Scale of Infant Development-II (Cho \& Park, 2006).

Development Inventory, K M-B CDI; Pae \& Kwak, 2011)를 사용하 여 측정하였다. SELSI는 생후 4-35개월 영유아의 전반적인 언어 및 의사소통 능력을 평가하기 위하여 고안된 검사로 수용언어와 표현 언어로 구성되어 있으며, 화용, 의미, 음운, 문법 등 영유아의 언어발 달에 대한 전반적인 정보를 제공해준다. $\mathrm{K} \mathrm{M-B} \mathrm{CDI는} \mathrm{Fenson} \mathrm{등}$ (2007)에 의해 개발된 M-B CDI 를 Pae와 Kwak (2011)이 한국판으 로 표준화한 검사도구로 영아용과 영유아용 두 가지 버전이 있으며 영아용(7-14개월)은 수용 및 표현어휘와 놀이, 제스처 등을, 유아 용(18-36개월)은 표현어휘와 문법을 평가한다. 본 연구에서는 12-30 개월 영유아를 대상으로 하므로 영아용과 유아용에 공통적으로 포함하는 표현어휘 수만을 측정하였다.

\section{연구 절차}

본 연구의 대상자 모집 및 모든 연구 절차는 한림대학교의 생명 윤리 위원회의 승인을 받았다. 연구 참가자는 한 곳의 종합병원과 미숙아 부모 모임, 그리고 육아관련 온라인 카페에 안내글을 게시 하여 모집하였으며, 참여를 희망한 어머니들과 개별적으로 연락하 여 검사 일정을 조율한 후, 어머니와 조율한 날짜와 시간에 가정으 로 방문하여 자료를 수집하였다. 먼저 자료 수집 전에 어머니에게 연구 목적과 절차 및 검사 내용 등을 설명하고 연구 참여에 대한 어 머니의 동의를 얻은 후 검사를 실시하였다. 부모보고 형식의 검사 실시를 위해 어머니에게 기본 정보 기록지, SELSI (Kim et al., 2003) 및 K M-B CDI (Pae \& Kwak, 2011) 작성 방법을 안내하였다. 두 검 사 모두 어머니가 직접 답하게 하였으며 이해하지 못한 문항은 연 구자가 다시 설명해주었다. 검사 응답을 완료한 후에는 답하지 않 은 문항이 있는지 검토하고, 빠진 문항이 있는 경우에는 검사자가
다시 확인 질문하여 모든 문항에 빠짐없이 답하게 하였다. 영유아 의 기본 발달을 확인하기 위해 실시한 K-BSID-II는 어머니가 검사 에 응답하기 전이나 후에 영유아가 검사에 응할 준비가 되어 있을 때를 고려하여 실시하였다.

\section{자료 측정}

SELSI의 결과는 언어발달연령-전체언어발달연령(CLA), 수용 언어발달연령(RLA), 표현언어발달연령(ELA)—과 각 영유아가 속 한 연령대에서 차지하는 백분위수(전체언어, 수용언어, 표현언어 영역에서의 백분위수)의 두 가지로 측정하였다. K M-B CDI 표현어 휘 결과도 표현어휘 수와 더불어 각 영유아가 속한 연령대에서 해 당 표현어휘 수가 차지하는 백분위수로 측정하였다. SELSI와 K M-B CDI 모두 (1) 백분위수 10 이하 $\leq 10 \%$ ile)에 해당하는 경우는 ‘언어발달지체', (2) 백분위수가 10-25 사이인 경우(11\%ile-25\%ile)는 ‘언어발달지체 위험', (3) 백분위수가 25를 초과하는 경우(>25\%ile) 는 ‘정상 범위'로 분류하고 각각이 차지하는 빈도를 측정하였다. 언 어발달지체를 백분위수에 기초하여 분류한 것은 연구에서 사용한 두 언어검사가 공통적으로 백분위수를 제공하였기 때문이다. 언어 발달지체의 기준을 백분위수 10 미만으로 한 것은 Thal과 Bates (1988)의 기준을 따랐으며, 영유아기 발달지체를 정의할 때 발달검 사 결과가 $25 \%$ 이하인 경우를 포함하는 경우가 많으므로(Lee, 2004) 11-25 백분위수에 해당하는 경우는 ‘언어발달지체 위험'으로 구분하였다.

\section{통계 분석}

측정 결과는 통계프로그램 IBM SPSS Statistics 21을 이용하여 
통계 분석 하였다.

\section{미숙아와 만삭아 집단의 언어수행 차이 분석}

두 집단의 언어수행 능력의 차이를 검정하기 위하여 SELSI의 언 어발달연령과 $\mathrm{KM}-\mathrm{B} \mathrm{CDI}$ 의 표현어휘 수를 종속측정치로 하여 두 독립표본 $t$-검정을 실시하였으며, 영유아 집단과 생활연령과의 상 호작용 효과를 살펴보기 위하여 영유아 집단(2)×연령(3)에 따라 이원분산분석(two-way ANOVA)을 실시하였다.

\section{미숙아 집단의 언어발달지체 출현빈도}

두 영유아 집단에서 언어발달지체 $(\leq 10 \%$ ile)와 언어발달지체 위 험군(11\%ile-25\%ile)이 차지하는 빈도를 각각 백분율을 통해 기술 적으로 살펴보고, 각 집단에서의 언어발달지체가 차지하는 빈도의 차이를 $\chi^{2}$ 검정을 통해 분석하였다.

\section{연구 결과}

\section{두 영유아 집단의 언어수행 차이 비교}

미숙아와 만삭아 집단의 언어수행 결과의 차이를 비교한 결과는

Table 2. Results of $t$-test for language tests between preterm and full-term toddler group

\begin{tabular}{cccc}
\hline & Preterm toddler & Full-term toddler & $t$ \\
\hline Total & & & \\
SELSI-RLA & $18.91(6.346)$ & $22.90(5.063)$ & $-4.441^{* * *}$ \\
SELSI-ELA & $17.34(7.027)$ & $22.03(5.765)$ & $-4.661^{* * *}$ \\
SELSI-CLA & $17.95(6.272)$ & $22.61(5.589)$ & $-5.014^{* * *}$ \\
K M-B CDI & $82.66(125.772)$ & $205.29(194.233)$ & $-4.851^{* * *}$ \\
12-18 mo & & & \\
SELSI-RLA & $13.35(3.327)$ & $18.22(3.590)$ & $-5.842^{* * *}$ \\
SELSI-ELA & $12.62(3.278)$ & $16.66(3.525)$ & $-4.923^{* * *}$ \\
SELSI-CLA & $12.76(3.209)$ & $17.34(3.543)$ & $-5.641^{* * *}$ \\
K M-B CDI & $10.11(12.115)$ & $48.28(48.297)$ & $-4.646^{* * *}$ \\
19-24 mo & & & \\
SELSI-RLA & $20.52(3.868)$ & $24.36(3.067)$ & $-3.751^{* * *}$ \\
SELSI-ELA & $18.57(7.58)$ & $23.28(3.506)$ & $-2.776^{* *}$ \\
SELSI-CLA & $19.09(4.146)$ & $24.00(3.240)$ & $-4.502^{* * *}$ \\
K M-B CDI & $45.14(60.795)$ & $200.52(140.380)$ & $-4.708^{* * *}$ \\
25-30 mo & & & \\
SELSI-RLA & $25.03(4.203)$ & $28.41(1.326)$ & $-3.228^{* *}$ \\
SELSI-ELA & $22.64(6.142)$ & $28.41(1.593)$ & $-4.283^{* * *}$ \\
SELSI-CLA & $23.96(4.678)$ & $28.68(1.524)$ & $-4.535^{* * *}$ \\
K M-B CDI & $206.68(150.358)$ & $439.09(138.938)$ & $-5.607^{* * *}$ \\
\hline
\end{tabular}

Values are presented as mean (SD).

PT = preterm toddler; $\mathrm{FT}$ = full-term toddler; SELSI=Sequenced Language Scale for Infants (Kim, Kim, Yoon, \& Kim, 2003); RLA = receptive language age; ELA= expressive language age; $C L A=$ combined language age; $K$ M-B CDI = Korean MacArthurBates Communication Development Inventory (Pae \& Kwak, 2011).

${ }^{* *} p<.01,{ }^{* * *} p<.001$.
Tables 2, 3과 같다. 미숙아 집단은 SELSI의 전체언어연령, 수용언어 연령, 표현언어연령과 K M-B CDI의 표현어휘 수에서 만삭아 집단 에 비해 유의하게 낮았다. 또한 두 집단의 수행을 12-18개월, 19-24 개월, 25- 30개월의 세 연령 수준으로 구분하여 비교한 결과에서도 모든 언어검사 결과가 각 연령군에서 유의하게 낮았다(Table 2).

두 영유아 집단의 언어검사 수행 차이가 연령집단과는 어떠한 상 호작용을 하는가를 살펴보기 위하여 영유아 집단(미숙아와 만삭 아)과 연령 수준(12-18개월, 19-24개월, 25-30개월)을 독립변수로 하여 이원변량분석을 실시한 결과 SELSI의 전체언어연령, 수용언 어연령, 표현언어연령과 $\mathrm{K} \mathrm{M}-\mathrm{B}$ CDI의 표현어휘 수에서 영유아 집 단과 연령 수준 각각의 주효과가 나타났다. 모든 언어검사 결과에 서 집단 주효과는 미숙아 집단이 만삭아 집단에 비해 유의하게 낮 은 수행으로 인한 것이었으며, 연령 수준 주효과는 세 연령군에서 유의한 차이로 인한 것이었다.

집단×연령 수준 간의 상호작용 효과는 K M-B CDI 표현어휘 수 에서만 나타났으며 SELSI 결과에서는 영유아 집단과 연령 수준 간 의 유의한 상호작용 효과가 관찰되지 않았다(Table 3). K M-B CDI

Table 3. Result of two-way ANOVA depending on toddler group and age group

\begin{tabular}{lccc}
\hline & Toddler group & Age & Toddler group $\times$ age \\
& $F_{(1,159)}$ & \multicolumn{1}{c}{$F_{(2,159)}$} & $F_{(2,159)}$ \\
\hline SELSI-RL & $52.305^{* * *}$ & $150.297^{* * *}$ & 1.094 \\
SELSI-EL & $44.837^{* * *}$ & $84.611^{* * *}$ & .520 \\
SELSI-CL & $70.847^{* * *}$ & $149.400^{* * *}$ & .028 \\
K M-B CDI & $77.460^{* * *}$ & $121.270^{* * *}$ & $13.631^{* * *}$ \\
\hline
\end{tabular}

SELSI = Sequenced Language Scale for Infants (Kim, Kim, Yoon, \& Kim, 2003); RL= receptive language; $E L=$ expressive language; $C L A=$ combined language; $K M-B$ $\mathrm{CDI}=$ Korean MacArthur-Bates Communication Development Inventory (Pae \& Kwak, 2011). ${ }^{* * *} p<.001$

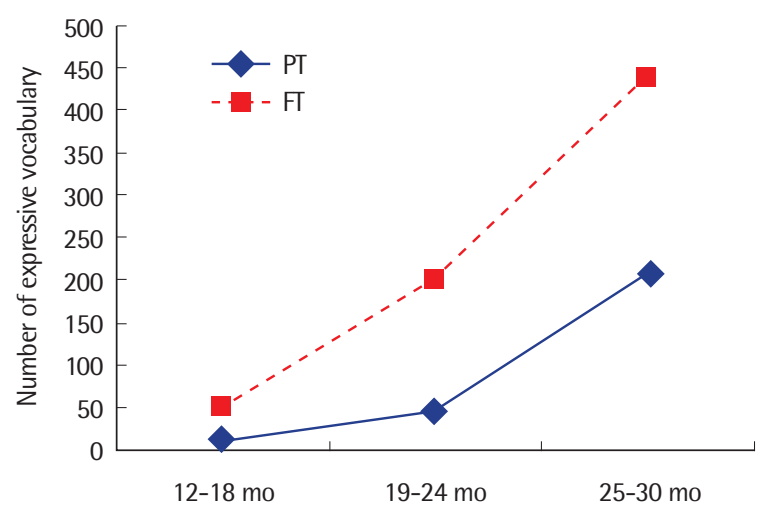

Figure 1. Number of expressive vocabulary (Korean MacArthur-Bates Communication Development Inventory) depending on age. PT = preterm toddler; $\mathrm{FT}=$ full-term toddler. 
YoonKyoung Lee, et al. • Prevalence of Developmental Language Delay in Preterm Toddlers

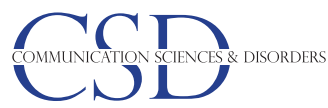

Table 4. Frequency and percentage of DLD between preterm and full-term groups depending on chronological age in months

\begin{tabular}{|c|c|c|c|c|c|c|c|c|c|c|c|c|}
\hline & \multicolumn{2}{|c|}{ Total } & \multirow{2}{*}{$\chi^{2}$} & \multicolumn{2}{|c|}{$12-18 \mathrm{mo}$} & \multirow{2}{*}{$\chi^{2}$} & \multicolumn{2}{|c|}{$19-24$ mo } & \multirow{2}{*}{$x^{2}$} & \multicolumn{2}{|c|}{$25-30 \mathrm{mo}$} & \multirow{2}{*}{$\chi^{2}$} \\
\hline & PT $(n=86)$ & $\mathrm{FT}(\mathrm{n}=79)$ & & PT $(n=37)$ & $\mathrm{FT}(\mathrm{n}=32)$ & & $\mathrm{PT}(\mathrm{n}=21)$ & $\mathrm{FT}(\mathrm{n}=25)$ & & PT (n=28) & $\mathrm{FT}(\mathrm{n}=22)$ & \\
\hline $\begin{array}{l}\text { SELSI-RL } \\
\quad \leq 10 \% \text { ile } \\
\text { 11\%ile-25\%ile } \\
>25 \% \text { ile }\end{array}$ & $\begin{array}{l}30(34.9) \\
21(24.4) \\
35(40.7)\end{array}$ & $\begin{array}{c}0(0) \\
6(7.6) \\
73(92.4)\end{array}$ & $51.499 * * *$ & $\begin{array}{r}14(37.8) \\
8(21.6) \\
15(40.5)\end{array}$ & $\begin{array}{c}0(0) \\
1(3.1) \\
31(96.9)\end{array}$ & $24.777^{* * *}$ & $\begin{array}{l}9(42.9) \\
4(19.0) \\
8(38.1)\end{array}$ & $\begin{array}{c}0(0) \\
4(16.0) \\
21(84.0)\end{array}$ & $14.590^{* *}$ & $\begin{array}{r}7(25.0) \\
9(32.1) \\
12(42.9)\end{array}$ & $\begin{array}{c}0(0) \\
1(4.5) \\
21(95.5)\end{array}$ & $15.356^{* * *}$ \\
\hline $\begin{array}{l}\text { SELSI-EL } \\
\quad \leq 10 \% \text { ile } \\
\text { 11\%ile-25\%ile } \\
>25 \% \text { ile }\end{array}$ & $\begin{array}{l}43(50.0) \\
12(14.0) \\
31(36.0)\end{array}$ & $\begin{array}{c}0(0) \\
11(13.9) \\
68(86.1)\end{array}$ & $56.677^{* * *}$ & $\begin{array}{r}24(64.9) \\
4(10.8) \\
9(24.3)\end{array}$ & $\begin{array}{c}0(0) \\
5(15.6) \\
27(84.4)\end{array}$ & $32.922^{* * * *}$ & $\begin{array}{l}9(42.9) \\
3(14.3) \\
9(42.9)\end{array}$ & $\begin{array}{c}0(0) \\
5(20.0) \\
20(80.0)\end{array}$ & $13.426^{* *}$ & $\begin{array}{r}10(35.7) \\
5(17.9) \\
13(46.4)\end{array}$ & $\begin{array}{c}0(0) \\
1(4.5) \\
21(95.5)\end{array}$ & $14.031^{* *}$ \\
\hline $\begin{array}{l}\text { SELSI-CL } \\
\quad \leq 10 \% \text { ile } \\
11 \% \text { ile-25\%ile } \\
>25 \% \text { ile }\end{array}$ & $\begin{array}{l}37(43.0) \\
24(27.9) \\
25(29.1)\end{array}$ & $\begin{array}{c}0(0) \\
8(10.1) \\
71(89.9)\end{array}$ & $66.865^{* * *}$ & $\begin{array}{r}20(54.1) \\
11(29.7) \\
6(16.2)\end{array}$ & $\begin{array}{c}0(0) \\
5(15.6) \\
27(84.4)\end{array}$ & $35.437^{* * *}$ & $\begin{array}{l}9(42.9) \\
5(23.8) \\
7(33.3)\end{array}$ & $\begin{array}{c}0(0) \\
3(12.0) \\
22(88.0)\end{array}$ & $17.040^{* * *}$ & $\begin{array}{r}8(28.6) \\
8(28.6) \\
12(42.9)\end{array}$ & $\begin{array}{c}0(0) \\
0(0) \\
22(100)\end{array}$ & $18.487^{* * *}$ \\
\hline $\begin{array}{l}\text { K M-B CDI-EV } \\
\leq 10 \% \text { ile } \\
11 \% \text { ile-25\%ile } \\
>25 \% \text { ile }\end{array}$ & $\begin{array}{l}40(46.5) \\
19(22.1) \\
27(31.4)\end{array}$ & $\begin{array}{c}0(0) \\
6(7.6) \\
73(92.4)\end{array}$ & $67.745^{* * *}$ & $\begin{array}{r}22(59.5) \\
6(16.2) \\
9(24.3)\end{array}$ & $\begin{array}{c}0(0) \\
4(12.5) \\
28(87.5)\end{array}$ & $31.962^{* * *}$ & $\begin{array}{l}6(28.6) \\
6(28.6) \\
9(42.9)\end{array}$ & $\begin{array}{c}0(0) \\
1(4.0) \\
24(96.0)\end{array}$ & $16.164^{* * *}$ & $\begin{array}{r}12(42.9) \\
7(25.0) \\
9(32.1)\end{array}$ & $\begin{array}{c}0(0) \\
1(4.5) \\
21(95.5)\end{array}$ & $20.881^{* * *}$ \\
\hline
\end{tabular}

Values are presented as number of toddlers (\%).

$\mathrm{PT}=$ preterm toddler; $\mathrm{FT}$ = full-term toddler; SELSI=Sequenced Language Scale for Infants (Kim, Kim, Yoon, \& Kim, 2003); RL= receptive language; EL=expressive language; $\mathrm{CLA}=$ combined language; $\mathrm{K}$ M-B CDI=Korean MacArthur-Bates Communication Development Inventory (Pae \& Kwak, 2011); EV=expressive vocabulary.

${ }^{* *} p<.01 ;{ }^{* * *} p<.001$

표현어휘 수에서의 상호작용 효과는 두 영유아 집단이 세 연령 수 준에서 모두 유의한 차이를 보였으나, 만삭아 집단은 세 연령 수준 간에 표현어휘 수가 비슷한 빈도로 증가한 반면, 미숙아 집단은 $12-18$ 개월과 19-24개월간에는 큰 증가를 보이지 않았다가 19-24개 월과 25-30개월간에 급속한 증가를 보여 두 영유아 집단이 연령 수 준에 따른 서로 다른 표현어휘 발달 패턴을 보인 것에서 비롯되었 다(Figure 1).

\section{미숙아와 만삭아 집단의 언어발달지체 및 발달지체 위험 출현율} 전체 집단에서의 출현율 및 출현빈도 비교

두 영유아 집단에서 언어발달지체 및 언어발달지체 위험군이 차 지하는 출현율과 $\chi^{2}$ 검정을 통해 출현빈도를 비교한 결과는 Table 4 와 같다. 미숙아 집단은 SELSI의 수용언어, 표현언어, 전체언어, $\mathrm{K}$ M-B CDI 표현어휘 결과에서 언어발달지체에 해당하는 경우가 $34.9 \%-50 \%$ 로 높은 비율을 보였다. 언어발달지체 위험에 해당하는 경우도 SELSI의 수용언어, 표현언어, 전체언어, K M-B CDI 표현어 휘에서 $14 \%-27.9 \%$ 로 언어발달지체 또는 언어발달지체 위험에 해 당하는 영유아가 전체의 $58 \%-70 \%$ 정도 해당하였다. 반면, 만삭아 집단은 언어발달지체에 해당하는 경우가 모든 언어검사에서 $0 \%$ 였 으며, 언어발달지체 위험에 해당하는 경우도 SELSI의 수용언어, 표 현언어, 전체언어, $\mathrm{K} \mathrm{M-B} \mathrm{CDI} \mathrm{표현어휘} \mathrm{각각에서} \mathrm{7.6 \% -13.9 \% 의} \mathrm{낮}$ 은 비율을 보였다.

미숙아와 만삭아 집단에서의 언어발달지체와 언어발달지체 위
험 영유아가 차지하는 빈도를 $\chi^{2}$ 검정을 통해 비교한 결과 SELSI의 수용언어, 표현언어, 전체언어, $\mathrm{K} \mathrm{M-B} \mathrm{CDI} \mathrm{표현어휘} \mathrm{모두} \mathrm{집단} \mathrm{간}$ 에 유의한 차이가 있었다(Table 4).

연령 수준에 따른 출현율 및 출현빈도 비교

두 영유아 집단에서 연령 수준에 따라 언어발달지체 및 언어발 달지체 위험군이 차지하는 비율을 보면, 미숙아 집단에서는 12-18 개월 모든 결과에서 언어발달지체에 해당하는 경우가 $37.8 \%-64.9 \%$ 였으며, 언어발달지체 위험에 해당하는 경우도 $10.8 \%-29.7 \%$ 로 나 타났다. 19-24개월에는 언어발달지체에 해당하는 경우가 SELSI 모 든 결과에서 $42.9 \%, \mathrm{~K} \mathrm{M}-\mathrm{B}$ CDI에서 $28.6 \%$, 언어발달지체 위험에 해당하는 경우는 각각 $14.3 \%-28.6 \%$ 였으며, 25-30개월에는 모든 결 과에서 언어발달지체에 해당하는 경우가 $25 \%-42.9 \%$, 언어발달지 체 위험에 해당하는 경우가 $17.9 \%-32.1 \%$ 로 세 연령 수준 모두에서 언어발달지체에 해당하는 영유아가 $40 \%$ 이상, 언어발달지체 위험 에 해당하는 영유아가 $10 \%-30 \%$ 로 나타났다. 반면, 만삭아 집단에 서는 세 연령 수준 모두에서 언어발달지체에 해당하는 경우가 없 었으며, 12-18개월에는 모든 언어검사 결과에서 언어발달지체 위험 에 해당하는 경우가 $3.1 \%-15.6 \%, 19-24$ 개월에는 $4 \%-20 \%$ 로 낮은 비율을 보였다. 25-36개월에는 4.5\%가 언어발달지체 위험에 해당 하였으며, 언어발달지체에 해당하는 영유아는 없었다.

각 연령 수준별로 미숙아와 만삭아 집단에서의 언어발달지체와 언어발달지체 위험 영유아 빈도를 $\chi^{2}$ 검정을 통해 비교한 결과 전체 
결과에서와 마찬가지로 세 연령집단에서 SELSI의 모든 결과와 K M-B CDI 표현어휘에서 유의한 차이가 있었다(Table 4).

\section{논의 및 결론}

본 연구는 미숙아 출생이 영유아의 언어발달에 영향을 미치는지 를 살펴보고자 하는 목적으로 실시되었다. 이를 위해 첫째, 미숙아 출생 영유아의 언어검사 수행 결과를 만삭아 출생 영유아와 비교 하여 살펴보고, 둘째, 각 집단에서 언어발달지체 혹은 언어발달지 체 위험에 해당하는 영유아의 출현율과 출현 빈도를 비교하였다.

\section{언어검사 수행 차이}

먼저 두 영유아 집단의 언어검사 수행 차이를 비교한 결과, 미숙 아 집단은 SELSI의 전체언어연령, 수용언어연령, 표현언어연령과 K M-B CDI의 표현어휘 수에서 만삭아 집단에 비해 유의하게 낮았 다. 미숙아 출생 영유아는 언어발달에서도 만삭아 출생 영유아들 에 비해 느리게 발달한다고 여러 논문에서 보고된 바 있다(Koldewijn et al., 2009; Lee \& Lee, 2013; Stolt et al., 2014; Taylor et al., 2001). 본 연구의 결과에서도 국외에서 보고된 바와 마찬가지로 미숙아로 출 생한 영유아의 언어발달이 유의하게 지체되어 동일한 결과를 보고 하였다.

연령이 증가함에 따라 언어발달의 차이가 달라지는가를 살펴보 기 위하여 영유아의 연령을 각각 12-18개월, 19-24개월, 25-30개월 의 세 수준으로 구분하여 비교하였다. 그 결과도 전체 결과에서와 마찬가지로 미숙아 출생 영유아 집단이 세 연령 수준에서 모두 만 삭아 집단에 비해 유의하게 낮은 언어검사 수행 결과를 보여 30 개 월까지도 지속적으로 또래에 비해 유의하게 낮은 언어발달을 보이 는 것으로 나타났다. 영유아 집단과 연령 수준 간의 상호작용을 통 해 살펴본 결과에서도 K M-B CDI 표현어휘를 제외한 SELSI로 측 정한 전체언어, 수용언어, 표현언어 결과에서 유의한 상호작용 효과 를 보이지 않아 미숙아 집단이 만삭아 집단에 비해 12-18개월부터 유의하게 느린 언어발달을 보이며 이러한 차이가 19-24개월, 25-30 개월의 연령 수준까지 유지되는 것으로 나타났다.

반면, K M-B CDI 표현어휘 결과에서는 영유아집단과 연령집단 간에 유의한 상호작용 효과가 나타났는데, 이는 만삭아 집단은 세 연령 수준 간에 표현어휘 수가 비슷한 빈도로 증가한 반면, 미숙아 집단은 12-18개월과 19-24개월간에는 큰 증가를 보이지 않았다가 19-24개월과 25-30개월간에 급속한 증가를 보여 두 영유아 집단이 연령 수준에 따른 서로 다른 표현어휘 발달 패턴을 보인 것에서 비 롯되었다. 일반적으로 영유아들은 24 개월 전후하여 표현어휘 수가
급성장하는 경향을 보인다(Bloom, 1991; Nelson, 1973). 본 연구에 서 만삭아 집단은 19-24개월에 표현어휘 수가 크게 증가한 반면 미 숙아 집단은 이보다 늦은 25-30개월의 시기에 표현어휘 수가 큰 폭 으로 증가하는 경향을 보였다. 이러한 결과 역시 미숙아 집단이 만 삭아 집단에 비해 지연된 언어발달을 보여주는 것이라 할 수 있다.

\section{언어발달지체 출현율}

두 영유아 집단에서 언어발달지체 또는 언어발달지체 위험군이 차지하는 비율을 살펴본 결과, 미숙아 집단은 SELSI와 K M-B CDI 표현어휘 결과에서 언어발달지체( $\leq 10 \%$ ile)에 해당하는 경우가 $34.9 \%-50 \%$, 언어발달지체 위험(11\%ile- $25 \% \mathrm{ile}$ )에 해당하는 경우는 $14 \%-27.9 \%$ 로 두 경우가 전체의 58\%-70\% 정도로 나타났다. 반면, 만삭아 집단은 언어발달지체에 해당하는 경우가 모든 언어검사에 서 $0 \%$ 였으며, 언어발달지체 위험에 해당하는 경우도 7.6\%-13.9\%의 낮은 비율을 나타내 미숙아 집단과 큰 차이가 있었으며, $\chi^{2}$ 검정을 통해 SELSI 및 K M-B CDI 결과에서 언어발달지체 및 언어발달지 체 위험군이 차지하는 빈도를 비교한 결과에서도 집단 간에 유의 한차이가 있었다.

외국에서 보고된 Wolk 등(2008)의 연구는 미숙아로 출생한 아 동을 6세가 된 시점에 추적해서 평가한 결과, 말-언어 검사 결과가 -2 표준편차 이하로 말-언어장애에 해당한 아동이 만삭아 집단에 비해 약 10 배 정도 많은 $10 \%-20 \%$ 였다고 보고하였다. 본 연구에서 는 Wolk 등(2008)이 보고한 것보다 높은 비율인 35\%-50\% 정도가 언어발달지체에 해당하였다. 이는 본 연구가 Wolk 등(2008)의 경 우보다 발달의 개인차가 심한 시기인 영유아를 대상으로 하였으며, 언어발달지체의 기준도 -2 표준편차보다 광범위한 10 백분위수 미 만 기준을 사용하여 나타난 차이일 수 있다. 출현율의 정도에서의 차이는 있으나 두 연구 모두 미숙아 출생 영유아 집단에서 유의하 게 더 높은 언어발달지체 출현율을 보였다는 점은 공통된 결과라 할수 있다.

연령이 증가함에 따라 언어발달지체 출현율에서 변화가 있는지 를 확인하기 위하여 두 영유아 집단을 세 연령 수준으로 나누어 언 어발달지체와 언어발달지체 위험이 차지하는 비율을 분석하였다. 그 결과 미숙아 집단은 $12-18$ 개월에는 언어발달지체가 $37.8 \%-64.9 \%$, 언어발달지체 위험은 $10.8 \%-29.7 \%$ 로 전체의 $58 \%-83 \%$ 가 언어발달 지체 혹은 언어발달지체 위험에 속하였다. 19-24개월에는 언어발달 지체가 28.6\%-42.9\%, 언어발달지체 위험은 각각 $14.3 \%-28.6 \%$ 로, 전체의 $56 \%-65 \%$ 가 언어발달지체 혹은 언어발달지체위험에 속하 였으며, 25-30개월에는 언어발달지체가 25\%-42.9\%, 언어발달지체 위험이 $17.9 \%-32.1 \%$ 로 $52 \%-67 \%$ 의 영유아가 언어발달지체 혹은 
YoonKyoung Lee, et al. • Prevalence of Developmental Language Delay in Preterm Toddlers

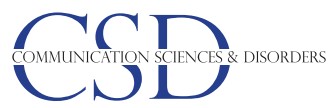

언어발달지체 위험에 속하였다. 12-18개월에 비해 19-24개월에 언 어발달지체 해당 비율이 약간 감소하였으나 유의한 차이는 없었으 며, 19-24개월과 25-30개월간에는 출현 비율에 큰 차이가 없었다. 반면, 만삭아 집단에서는 세 연령집단 모두에서 언어발달지체 위험 에 해당하는 경우가 $12-18$ 개월에는 $3.1 \%-15.6 \%, 19-24$ 개월에는 $4 \%-20 \%, 25-36$ 개월에는 $4.5 \%$ 나타났을 뿐 언어발달지체에 해당 하는 영유아는 없어 두 영유아 집단 간에 큰 차이를 보였으며, $\chi^{2}$ 검 정을 통한 SELSI 및 K M-B CDI 결과에서 언어발달지체 및 언어발 달지체 위험군이 차지하는 빈도를 비교한 결과에서도 언어발달지 체와 언어발달지체 위험의 빈도에서 유의한 차이를 보였다. 이러한 결과는 두 집단의 언어검사수행 차이 비교 결과와마찬가지로 12-18 개월부터 25-30개월까지 언어발달지체나 언어발달지체 위험에 해 당하는 미숙아의 비율이 크게 변하지 않으며, 또래 집단에 비해서 언어발달지체 또는 언어발달지체 위험 출현율이 유의하게 높음을 보여 준다.

본 연구의 결과는 미숙아 출생 영유아의 언어발달이 만삭아 집 단에 비해 유의하게 느릴 뿐 아니라, 언어발달지체는 35\%-50\%, 언 어발달지체 위험은 $10 \%$ 내외로 전체 절반 이상의 영유아가 언어발 달지체 또는 발달지체 위험에 있다는 것을 보여 주었다. 이러한 연 구 결과는 미숙아 출생 영유아를 대상으로 조기언어중재를 제공 하는 것이 필요함을 시사한다. 발달이 지연되거나 발달지연의 위험 에 있는 영유아들에게 발달장애를 예방하거나 최소화하기 위해 조기중재가 무엇보다 중요하다는 것은 여러 문헌을 통해 강조되어 왔다. 특히 언어발달은 일상생활은 물론 발달 전반에 큰 영향을 미 치므로 조기중재가 무엇보다 중요하다(Lee, 2011).

본 연구는 미숙아 출생 영유아 집단에서의 언어발달 출현율을 제시함으로써 이들에 대한 조기중재의 필요성을 제시하였다는 점 에서 의의가 있으나, 생후 30 개월까지의 영유아만을 대상으로 하였 다는 제한점이 있다. 언어발달은 다른 발달영역에 비해 개인차가 큰 발달영역이므로 30 개월 이후 시기까지 미숙아 출생 아동의 언 어발달을 추적하여 살펴봄으로써 언어발달 양상이나 언어발달지 체 출현율의 변화를 살펴보는 것이 필요함을 제언으로 한다.

\section{REFERENCES}

Bhutta, A. T., Cleves, M. A., Casey, P. H., Cradock, M. M., \& Anand, K. J. S. (2002). Cognitive and behavioral outcomes of school-aged children who were born preterm: a meta-analysis. Journal of the American Medical Association, 288, 728-737.

Billeaud, F. P. (2003). Communication disorders in infants and toddlers: assess- ment and intervention. St. Louis, MO: Butterworth-Heinemann.

Bloom, L. (1991). Language development from two to three. Cambridge: Cambridge University Press.

Cho, B. H., \& Park, H. W. (2006). Korean-Bayley Scales of Infant Development II (K-BSID-II). Seoul: Mindpress.

Fenson, L., Marchamn, V., Thal, D., Dale, P. S., Bates, E., \& Reznick, J. S. (2007). The MacArthur-Bates Communicative Development Inventories: user's guide and technical manual (2nd ed.). Baltimore: Paul G. Brookes Publishing.

Kang, J. W., \& Lee, K. S. (2007). Prognostic factors of developmental delay in premature infants. Journal of Korea Child Neurology Society, 15, 67-74.

Kim, J. (2005). Effects of a massage program on growth of premature infants and on confidence and satisfaction in the mothering role. Child Health Nursing Research, 11, 381-389.

Kim, Y. T., Kim, K. H., Yoon, H. R., \& Kim, H. S. (2003). Sequenced Language Scale for Infants (SELSI). Seoul: Special Education publishing.

Koldewijn, K., Wolf, M. J., van Wassenaer, A., Meijssen, D., van Sonderen, L., van Baar, A., ..., \& Kok, J. (2009). The Infant Behavioral Assessment and Intervention Program for very low birth weight infants at 6 months corrected age. Journal of Pediatrics, 154, 33-38.

Lee, H. J., \& Lee, Y. (2013). Literature review of premature child's communicative and language. Korean Journal of Early Childhood Special Education, $13,327-346$.

Lee, H. J., \& Lee, Y. (2014). Characteristics of social communication behavior in preterm toddlers. Korean Journal of Early Childhood Special Education, $14,105-120$.

Lee, N. H. (2014). Ways to improve prenatal care in a low-fertility Korea. Health and Welfare Policy Forum, 217, 64-74.

Lee, S. H. (2004). Early childhood special education. Seoul: Hakjisa.

Lee, Y. (2011). The relationships among language, communicative abilities and motor, cognitive and socio-emotional development in toddlers with language delays. Korean Journal of Communication Disorders, 16, 1-12.

Marlow, N., Roberts, L., \& Cooke, R. (1993). Outcome at 8 years for children with birth weights of $1250 \mathrm{~g}$ or less. Archives of Disease in Childhood, 68, 286-290

Marlow, N., Wolke, D., Bracewell, M. A., \& Samara, M. (2005). Neurologic and developmental disability at six years of age after extremely preterm birth. New England Journal of Medicine, 352, 9-19.

Nelson, K. (1973). Structure and strategy in learning to talk. Monographs of the Society for Research in Child Development, 38, 1-135.

Oh, M. H., Lee, I. K., Lee, H. J., \& Kim, S. Y. (2004). The developmental eval- 
uation in preterms at risk, full-terms at risk, and normal infants. Korean Journal of Psychology: General, 23, 27-49.

Pae, S., \& Kwak, K. C. (2011). Korean MacArthur-Bates Communicative De velopment Inventories (K $M-B C D I)$ : user's guide and technical manual. Seoul: Mindpress.

Park, H. R. (2010). Qualitative comparison study on status of support for premature infants: focus on prematurity home care (Master's thesis). Sungkyunkwan University, Seoul, Korea.

Phillips, M. E. (2006). Does the language of children born less than 28-weeks gestation differ from language-age matched pairs? (Master's thesis). University of Canterbury, Christchurch, New Zealand.

Roberts, G., Howard, K., Spittle, A. J., Brown, N. C., Anderson, P. J., \& Doyle, L. W. (2008). Rates of early intervention services in very preterm children with developmental disabilities at age 2 years. Journal of Paediatrics and Child Health, 44, 276-280.

Rossetti, L. M. (2001). Communication intervention: birth to three. San Diego,

\section{CA: Cengage Learning.}

Schirmer, C. R., Portuguez, M. W., \& Nunes, M. L. (2006). Clinical assessment of language development in children at age 3 years that were born preterm. Arquivos de Neuro-Psiquiatria, 64, 926-931.

Stolt, S., Korja, R., Matomäki, J., Lapinleimu, H., Haataja, L., \& Lehtonen, L. (2014). Early relations between language development and the quality of mother-child interaction in very-low-birth-weight children. Early Human Development, 90, 219-225.

Thal, D., \& Bates, E. (1988). Language and gesture in late talkers. Journal of Speech, Language, and Hearing Research, 31, 115-123.

Taylor, H. G., Klein, N., Minich, N. M., \& Hack, M. (2001). Long-term family outcomes for children with very low birth weights. Archives of Pediatrics \& Adolescent Medicine, 155, 155-161.

Wolke, D., Samara, M., Bracewell, M., \& Marlow, N. (2008). Specific language difficulties and school achievement in children born at 25 weeks of gestation or less. Journal of Pediatrics, 152, 256-262. 


\section{국문초록}

\section{미숙아 출생 영유아의 언어발달지체 출현율}

이윤경 $\cdot$ 이효주 ${ }^{2}$

'한림대학교 언어청각학부, 2한림대학교 대학원 언어병리청각학과

배경 및 목적: 미숙아 출생은 영유아기 언어발달지연의 주된 요인 중 하나로 알려져 있다. 본 연구는 미숙아로 출생한 영유아 집단의 언 어발달지체 출현율을 만삭아 집단과 비교하여 살펴보고자 하였다. 방법: 연구 대상은 초기 언어습득기에 해당하는 12-30개월 사이의 미숙아 86명과 만삭아 79명, 총 165 명의 영유아였다. 두 영유아 집단은 월령에 따라 12-18개월, 19-24개월, 25-30개월의 세 연령집단으 로 구분하였다. 언어능력은 SELSI와 K M-B CDI로 측정하였다. 두 집단의 언어검사수행 결과를 t-test와 two-way ANOVA로 분석하였 으며, 언어발달지체 및 언어발달지체 위험 출현빈도를 $\chi^{2}$ 을 통해 통계분석 하였다. 결과: 미숙아 출생 집단은 전체와 세 연령집단 모두 에서 SELSI의 통합언어연령, 수용언어연령, 표현언어연령과 K M-B CDI의 표현어휘 수에서 유의하게 낮은 수행을 보였다. 영유아집단 과 연령 간의 상호작용효과는 K M-B CDI에서만 관찰되었다. 미숙아 출생 영유아 집단이 언어발달지체와 언어발달지체 위험군 출현율 이 높았으며, $\chi^{2}$ 을 통한 출현빈도 비교에서도 유의한 차이를 보였다. 논의 및 결론: 연구 결과에 기초하여 미숙아 출생 영유아의 언어지 연을 예방하기 위한 대한 조기 언어중재의 중요성에 대해 논의하였다.

핵심어: 미숙아, 언어발달, 언어발달지체, 언어발달지체 위험군

본 연구는 2014년 정부(교육부)의 재원으로 한국연구재단(NRF-2014S1A5A2A01015713)과 2015학년도 한림대학교 교내 학술연구비(HRF201512-008)의 지원을 받아 수행되었음.

\section{참고문헌}

강준원, 이건수(2007). 미숙아에서 발달 장애의 예후인자. 대한소아신경학회지, 15, 67-74.

김영태, 김경희, 윤혜련, 김화수(2003). 영유아언어발달검사(SELSI). 서울: 도서출판 특수교유.․

김지영(2005). 미숙아 마사지 교육 프로그램이 미숙아의 성장과 어머니 역할수행에 대한 자신감 및 만족도에 미치는 효과. 아동간호학회지, 11, 381-

389.

박해령(2010). 미숙아지원 실태에 대한 질적 연구: 미숙아양육 가정을 중심으로. 성균관대학교 사회복지대학원 석사학위논문.

배소영, 곽금주(2011). 맥아더-베이츠 의사소통발달 평가 전문가 지침서. 서울: 마인드프레스.

오명호, 이인규, 이희정, 김선영(2004). 위험군 영아에 대한 발달 평가. 한국심리학회지: 일반, 23, 27-49.

이난희(2014). 저출산시대 산모와 출생아의 건강을 위한 산전관리 내실화. 보건복지포럼, 217, 64-74.

이소현(2004). 유아특수교육. 서울: 학지사.

이윤경(2011). 언어발달지체 영유아의 언어 및 의사소통 능력과 인지, 운동 및 사회성 발달과의 관계. 언어청각장애연구, 16, 1-12.

이효주, 이윤경(2013). 미숙아 출생 영유아의 언어 및 의사소통 발달 연구 동향. 유아특수교육연구, 13,327-346.

이효주, 이윤경(2014). 미숙아출생 영유아의 사회적 의사소통 행동 특성. 유아특수교육연구, 14, 105-120.

조복희, 박혜원(2006). 한국-베일리 영유아발달검사(K-BSID-II). 서울: 마인드프레스. 